\title{
EDUCATION DATA MINING UNTUK MENENTUKAN KELOMPOK BELAJAR UJIAN NASIONAL DI SMK
}

\author{
Ninik Tri Hartanti \\ Sistem Informasi, Ilmu Komputer, Universitas AMIKOM Yogyakarta \\ Email :ninik.t@amikom.ac.id
}

\begin{abstract}
Abstrak
Pengayaan materi untuk materi ajar merupakan salah satu persiapan siswa untuk menempuh ujian nasional. SMK Syubbanul Wathon Magelang dalam menerapkan langkah ini hanya dengan melihat nilai rapor semester 1 sampai dengan semester 5, sehingga proses pengelompokan kemampuan siswa untuk pengayaan materi ajar di SMK SW masih belum maksimal. Oleh karena itu,untuk menambah keakuratan data maka diperlukan data nilai tambahan yaitu berupa tes tulis sesuai dengan kemampuan siswa. Metode K-means clustering digunakan untuk mengatasi masalah tersebut. Data yang digunakan untuk pengelompokan kemampuan siswa ini adalah data rapor semester 1 sampai dengan semester 5 dan nilai tes tulis, sehingga akan terbentuk kelompok belajar yang sesuai dengan kemampuan siswa,. Penelitian ini menghasilkan proses K-Means sebanyak 6 kali, dan jumlah siswa untuk kelompok IND cluster 1 terdapat 24 siswa, cluster 2 terdapat 43 siswa, dan cluster 3 terdapat 44 siswa, dan untuk kelompok ING cluster 1 terdapat 131 siswa, cluster 2 dan cluster 3 tidak ada siswa, kelompok MAT cluster 1 terdapat 7 siswa, cluster 2 terdapat 114 siswa, dan cluster 3 tidak ada siswa, kelompok MM cluster 1 dan cluster 3 tidak ada siswa, tetapi cluster 2 terdapat 120 siswa, kelompok PAI cluster 1 terdapat 31 siswa, cluster 2 terdapat 36 siswa, dan cluster 3 terdapat 21 siswa, kelompok PPKN cluster 1 dan cluster 2 tidak ada siswa, tetapi cluster 3 terdapat 100 siswa, selanjutnya kelompok KKPI cluster 1 terdapat 30 siswa, cluster 2 terdapat 50 siswa, dan cluster 3 terdapat 42 siswa.
\end{abstract}

Kata kunci: K-Means, kelompok belajar, Clustering, Education data Mining

\section{Pendahuluan}

Berdasarkan Undang-Undang Republik Indonesia nomor 20 tahun 2003, evaluasi pendidikan adalah kegiatan pengendalian, penjaminan dan penetapan mutu pendidikan terhadap berbagai komponen pendidikan pada setiap jalur, jenjang, dan jenis pendidikan sebagai bentuk pertanggungjawaban penyelenggaraan pendidikan (UU pendidikan no.20 th. 2003).

Evaluasi pendidikan yang diterapkan di Indonesia secara serentak diantaranya adalah ujian nasional dan ujian sekolah berbasis nasional (USBN) untuk pendidikan dasar dan menengah. Ujian Nasional yang biasa disingkat UN adalah kegiatan pengukuran capaian kompetensi lulusan pada mata pelajaran tertentu secara nasional dengan mengacu pada standar kompetensi lulusan, sedangkan ujian sekolah berstandar nasional atau USBN adalah kegiatan pengukuran capaian kompetensi peserta didik yang dilakukan satuan pendidikan untuk mata pelajaran tertentu dengan mengacu pada standar kompetensi lulusan untuk memperoleh pengakuan atas prestasi belajar (Permendikbud no.14 th. 2017).

Memperbaiki mutu pendidikan di SMK Syubbanul Wathon Magelang diterapkan adanya sistem pembagian kelompok belajar yang akan memberikan pengayaan materi ajar untuk peserta didiknya agar sukses mengikuti UN dan USBN. Sistem pembagian kelompok belajar di SMK Syubbanul Wathon akan menggunakan data nilai rapor semester 1 sampai dengan semester 5 disertai dengan nilai UTUL (Ujian tertulis) yang diberikan di semester 5. Algoritma K-Means dapat membantu untuk menyelesaikan sistem pembagian kelompok ini, dengan mengkombinasikan algoritma AHP maka akan dengan mudah diketahui perangkingan peserta didik untuk tiap cluster dalam tiap materi ajar. Adapun materi ajar yang akan diberikan adalah materi ajar UN SMK (Matematika, Bahasa Indonesia, Bahasa Inggris, PPKN, PAI) dan USBN SMK (MM atau KKPI).

\section{Pembahasan}

\subsection{Metodologi Penelitian}

Tahapan yang pertama adalah pengumpulan data siswa kelas XII jurusan TKJ dan MM, data rapor siswa dari kelas X-XII mulai dari semester I sampai semester V yang terdiri dari nilai mata pelajaran Bahasa Indonesia, Bahasa Inggris, Matematika, Multimedia, PAI, PPKN, dan KKPI. Tahap yang kedua adalah wawancara dilakukan dengan pihak kurikulum SMK SW tentang kriteria dan penilaian mata pelajaran yang diberikan sehubungan dengan mata pelajaran UN dan USBK. Tahap ketiga adalah kepustakaan dengan mencari sumber atau literatur yang sesuai, tahap keempat adalah merupakan pembangunan perangkat lunak dengan metode prototype.

Tahapan di mekanisme pengembangan sistem dengan prototype dalam penerapan metode prototype adalah: (Abdul Kadir 2003)

1. Mengidentifikasi kebutuhan pemakai. Tahap ini dilakukan pengumpulan data, wawancara tentang kebutuhan apa yang diinginkan dari sistem, dan literatur yaitu dokumentasi terhadap kebutuhan yang diinginkan pemakai.

2. Membuat prototype. Tahap ini adalah membuat perancangan sementara untuk memperlihatkan kepada pemakai model sistem yang akan dirancang. 
3. Pengujian prototype. Tahap ini dilakukan uji coba sistem yang telah dirancang untuk memastikan bahwa sistem tersebut dapat digunakan dengan baik dan benar sesuai kebutuhan pemakai.

4. Memperbaiki prototype. Tahap ini akan menentukan apakah sistem dapat diterima pemakai atau harus dilakukan perbaikan, setelah adanya perbaikan maka dilakukan pengujian prototype kembali.

5. Mengembangkan versi produksi. Pada tahap ini akan menyelesaikan sistem sesuai dengan masukan terakhir dari pemakai dan memberikan gambaran bagaimana penggunaan sistem tersebut kepada pemakai.

Mekanisme pengembangan sistem dengan prototype terlampir di Gambar 1. Langkah selanjutnya adalah menerapkan algoritma K-Means yang terdapat di Gambar 2 sehingga algoritma klastering $K$-means dapat diringkas sebagai berikut (Santoso B, 2007) :

1. Pilih jumlah klaster

2. Inisialisasi $\mathrm{k}$ pusat klaster (diberi nilai-nilai random ).

3. Tempatkan setiap data/obyek ke klaster terdekat. Kedekatan dua obyek ditentukan bersarkan jarak kedua obyek tersebut. Jarak paling dekat antara satu data dengan satu klaster tertentu akan menentukan suatu data masuk dalam klaster mana.

4. Hitung kembali pusat klaster dengan anggota klaster yang sekarang. Pusat klaster adalah ratarata semua data/obyek dalam klaster.

5. Tugaskan lagi setiap obyek memakai pusat klaster yang baru. Jika pusat Klaster sudah tidak berubah lagi, maka proses pengklasteran selesai.

6. Kembali ke langkah 3 sampai pusat klaster tidak berubah lagi.

Berikut adalah persamaan untuk mengukur jarak :

$$
d_{(x, y)}=\|x-y\|^{2}=\sqrt{\sum_{i=1}^{n}(x i-y i)^{2}} \quad \ldots .1
$$

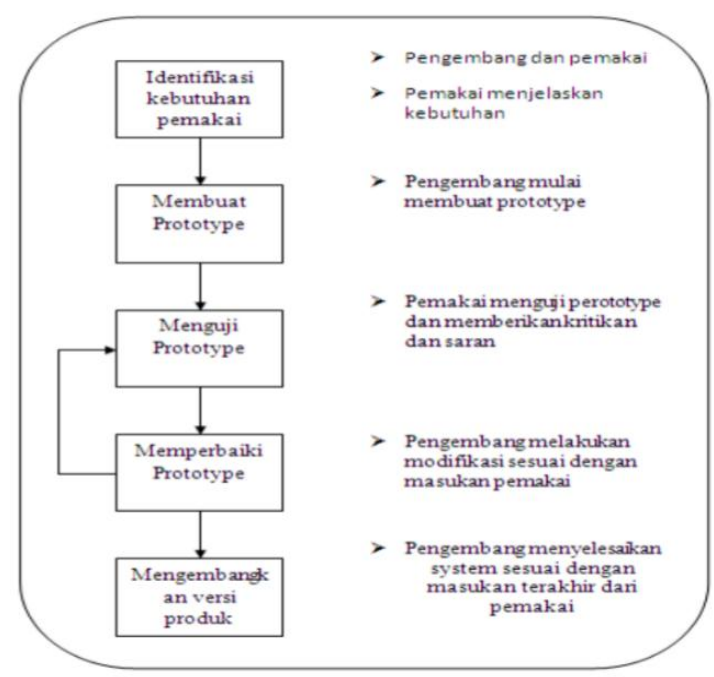

Gambar 1. Mekanisme Pengembangan Sistem dengan Prototype (Sumber : Abdul Kadir)

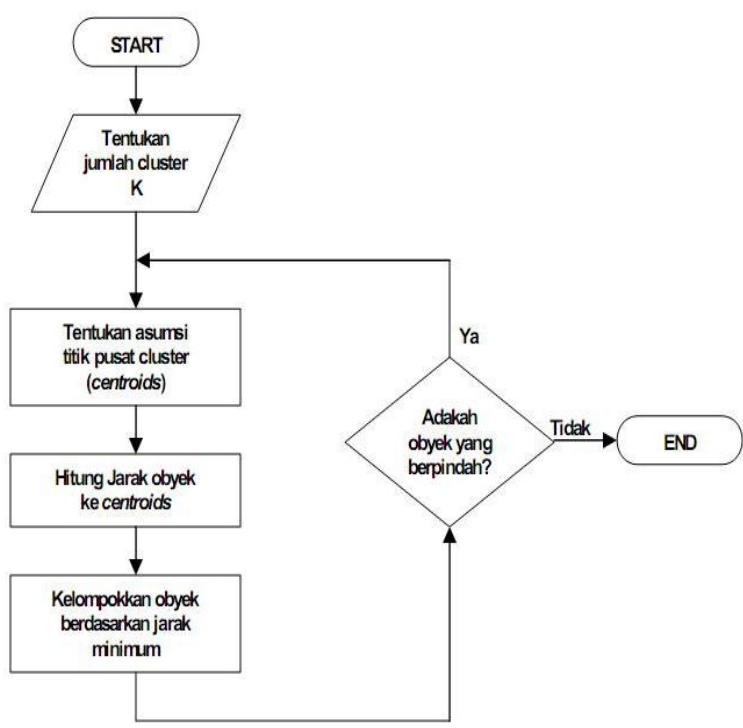

Gambar 2. Algoritma K-Means

\subsection{Metode Perancangan}

Context diagram pada Gambar $\mathbf{3}$ berikut ini memperlihatkan adanya diagram masukan ke sistem dan keluaran dari sistem.

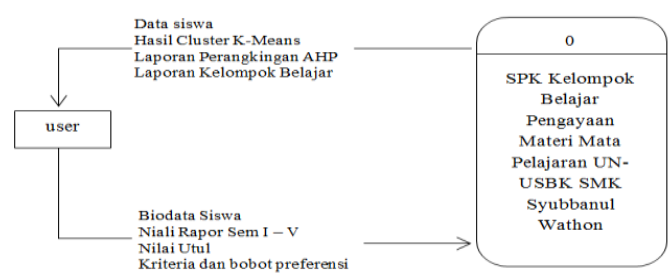

Gambar 3. Context Diagram

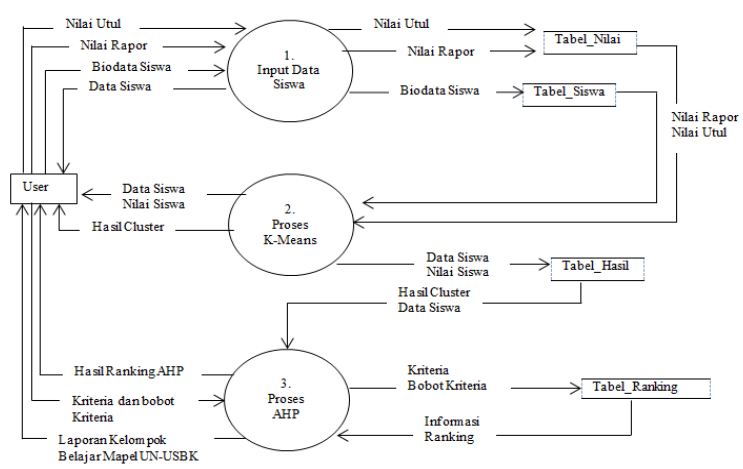

Gambar 4. DFD Level 1

DFD level 1 tersebut diatas, pada proses pertama input data siswa, user memasukkan nilai utul, nilai rapor dan biodata siswa yang kemudian data tersebut disimpan ke dalam tabel Tabel_Nilai dan Tabel_Siswa. Selanjutnya user dapat feedback nya berupa informasi data siswa. Proses kedua merupakan proses perhitungan K-Means, 
yang menggunakan Tabel_Nilai dan Tabel_Siswa sehingga user mendapatkan feddback nya berupa data siswa, nilai siswa dan hasil clusternya. Perhitungan AHP terdapat di proses ketiga, semua data yang dihasilkan dari proses kedua akan digunakan dalam proses ketiga ini. Hasil akhirnya adalah user akan dapat feedback berupa informasi hasil ranking AHP, kriteria dan bobot kriteria, serta laporan kelompok belajar mata pelajaran UNUSBK.

\subsection{Data yang dibutuhkan}

Penerapan algoritma K-Means untuk menentukan kelompok belajar dalam rangka persiapan ujian nasional SMK Syubbanul Wathon ini membutuhkan beberapa data, diantaranya adalah data nilai raport dan nilai placement test sesuai mata pelajaran untuk ujian nasional. Data nilai rapor terdiri dari nilai mata pelajaran Bahasa Indonesia, Bahasa Inggris, Matematika, Multimedia, Pendidikan Agama Islam (PAI), Pendidikan Kewarganegaraan (PPKn), dan KKPI (Keterampilan Komputer dan Pengelolaan Informasi). Data nilai tersebut melibatkan seluruh siswa di kelas 3 (angkatan Jadda) sejumlah 151 siswa. Berikut tabel nilai rapor dan nilai placement test.

Tabel 1. Nilai rapor semester 1,2, 3 (23 siswa)

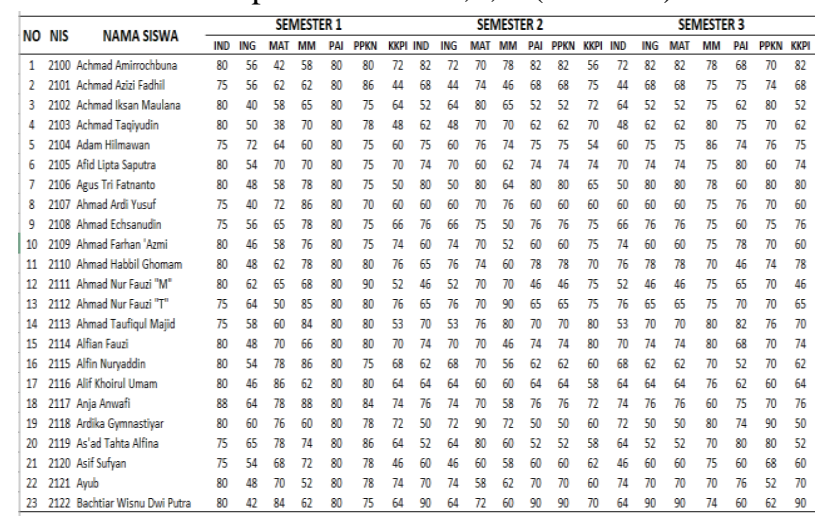

Tabel 2. Nilai rapor semester 4 dan 5 (23 siswa)

\begin{tabular}{|c|c|c|c|c|c|c|c|c|c|c|c|c|c|c|c|c|}
\hline \multirow{2}{*}{ No } & & \multirow{2}{*}{ NAMA SISWA } & \multicolumn{7}{|c|}{ SEMESTER 4} & \multicolumn{7}{|c|}{ SEMESTER 5} \\
\hline & & & IND & ING & MAT & MM & PAI & & KKPI & IND & ING & & & PAI & & \\
\hline & $0 \mathrm{~A}$ & Achmad & 70 & 72 & 82 & 60 & 75 & 75 & 70 & 78 & 70 & 72 & 82 & 86 & 82 & \\
\hline & $\mathrm{B} 1 \mathrm{~A}$ & Achn & & 44 & 68 & 58 & 70 & 75 & 58 & & 58 & 44 & 68 & & 68 & \\
\hline & $2 \mathrm{~A}$ & Achn & & 64 & 52 & 72 & 75 & 70 & & & 6 & 64 & & & 5 & \\
\hline & & Achma & 70 & 48 & 62 & 66 & 80 & 75 & 50 & 80 & 50 & 48 & 6 & & 62 & \\
\hline & $2104 \mathrm{~A}$ & Adam $\mathrm{H}$ & 76 & 60 & 75 & 68 & 86 & 82 & 65 & 86 & 65 & 60 & 75 & & & \\
\hline & $2105 \mathrm{~A}$ & Afid Lipta & 60 & 70 & 74 & 62 & 75 & 68 & 60 & 75 & 60 & 70 & 74 & 70 & 74 & \\
\hline & & Agus & & 50 & 80 & 72 & 78 & 52 & 70 & 78 & 77 & 50 & 80 & & 80 & \\
\hline & & & & 60 & 60 & & & & & & & & & & & \\
\hline & & & & 66 & 76 & 56 & 75 & 75 & 8 & & 86 & 66 & & & 70 & \\
\hline & $2109 \mathrm{~A}$ & Ahmad & 70 & 74 & 60 & 46 & 75 & 74 & 78 & 75 & 78 & 74 & 60 & & 60 & \\
\hline & $2110 \mathrm{~A}$ & Ahma & 74 & 76 & 75 & 62 & 70 & 80 & 76 & 70 & 76 & 76 & 78 & 78 & 78 & \\
\hline & & & & & & & & & & & & & & & 46 & \\
\hline & & & & & & & & & & & & & & & & \\
\hline & & & & 53 & 7 & 5 & & & & & & & & & & \\
\hline & $2114 \mathrm{~A}$ & & & 70 & 74 & 58 & 80 & 78 & 84 & 80 & 84 & 70 & 7 & & 74 & \\
\hline & & & & 68 & $6 ?$ & & 56 & 46 & & 8 & & 68 & & & 62 & \\
\hline & & & & 64 & 64 & 62 & & 65 & & & 85 & 64 & 64 & & 64 & \\
\hline & & & & 7 & & & & & & & & & & & & \\
\hline & 21 & & & $t$ & & & & & & & & & & & & \\
\hline & . & & & & & & & & & & & & & & & \\
\hline & 21 & As & & 46 & 60 & 60 & 74 & 64 & 14 & 14 & 74 & 46 & 60 & & 60 & \\
\hline & & & & & & & & & & & & & & & & \\
\hline & & & & & & & & & & & & & & & & \\
\hline
\end{tabular}

Tabel 3. Nilai Placement Test (23 siswa)

\begin{tabular}{|c|c|c|c|c|c|c|c|c|c|}
\hline \multirow{2}{*}{ No } & \multirow{2}{*}{ NIS } & \multirow{2}{*}{ NAMA SISWA } & \multicolumn{7}{|c|}{ PLACEMENT TEST } \\
\hline & & & IND & ING & MAT & MM & PAI & PPKN & KKPI \\
\hline 1 & 2100 & Achmad Amirrochbuna & 75 & 70 & 65 & 82 & 75 & 50 & 50 \\
\hline 2 & 2101 & Achmad Azizi Fadhil & 80 & 58 & 60 & 68 & 70 & 52 & 52 \\
\hline 3 & 2102 & Achmad Iksan Maulana & 70 & 62 & 76 & 80 & 75 & 60 & 60 \\
\hline 4 & 2103 & Achmad Taqiyudin & 55 & 50 & 85 & 62 & 80 & 70 & 70 \\
\hline 5 & 2104 & Adam Hilmawan & 65 & 65 & 78 & 80 & 86 & 90 & 90 \\
\hline 6 & 2105 & Afid Lipta Saputra & 85 & 75 & 46 & 74 & 75 & 68 & 80 \\
\hline 7 & 2106 & Agus Tri Fatnanto & 75 & 70 & 65 & 80 & 78 & 70 & 46 \\
\hline 8 & 2107 & Ahmad Ardi Yusuf & 65 & 78 & 65 & 80 & 75 & 84 & 56 \\
\hline 9 & 2108 & Ahmad Echsanudin & 55 & 86 & 74 & 76 & 75 & 66 & 65 \\
\hline 10 & 2109 & Ahmad Farhan 'Azmi & 70 & 78 & 62 & 60 & 75 & 85 & 72 \\
\hline 11 & 2110 & Ahmad Habbil Ghomam & 85 & 76 & 64 & 78 & 70 & 75 & 70 \\
\hline 12 & 2111 & Ahmad Nur Fauzi "M" & 55 & 65 & 75 & 80 & 75 & 75 & 54 \\
\hline 13 & 2112 & Ahmad Nur Fauzi "T" & 65 & 68 & 50 & 80 & 75 & 75 & 74 \\
\hline 14 & 2113 & Ahmad Taufiqul Majid & 80 & 70 & 52 & 70 & 80 & 76 & 42 \\
\hline 15 & 2114 & Alfian Fauzi & 85 & 84 & 60 & 74 & 80 & 85 & 65 \\
\hline 16 & 2115 & Alfin Nuryaddin & 70 & 66 & 70 & 80 & 56 & 80 & 60 \\
\hline 17 & 2116 & Alif Khoirul Umam & 75 & 86 & 90 & 64 & 75 & 60 & 52 \\
\hline 18 & 2117 & Anja Anwafi & 60 & 62 & 68 & 76 & 72 & 70 & 64 \\
\hline 19 & 2118 & Ardika Gymnastiyar & 50 & 78 & 70 & 50 & 70 & 90 & 58 \\
\hline 20 & 2119 & As'ad Tahta Alfina & 74 & 60 & 84 & 52 & 54 & 80 & 46 \\
\hline 21 & 2120 & Asif Sufyan & 80 & 74 & 66 & 60 & 74 & 46 & 76 \\
\hline 22 & 2121 & Ayub & 60 & 75 & 85 & 70 & 65 & 56 & 82 \\
\hline 23 & 2122 & Bachtiar Wisnu Dwi Putra & 76 & 82 & 62 & 90 & 60 & 75 & 75 \\
\hline
\end{tabular}

\subsection{Perhitungan K-Means}

Proses perhitungan K-Means melibatkan tabel 1, tabel 2 dan tabel 3. Berdasarkan tabel tersebut, akan diambil nilai rata-rata untuk setiap mata pelajaran, yang kemudian akan ditentukan secara acak untuk menentukan pusat cluster (centroid) awal. Data nilai rata-rata akan ditampilkan di tabel 4, sedangkan data pusat cluster awal ditampilkan di tabel 5 dan 6 seperti berikut ini.

Tabel 4. Nilai Rata-rata (23 siswa)

\begin{tabular}{|c|c|c|c|c|c|c|c|c|c|}
\hline \multirow{2}{*}{ No } & \multirow{2}{*}{ NIS } & \multirow{2}{*}{ NAMA SISWA } & \multicolumn{7}{|c|}{ NILAI MAPEL UN-USBN } \\
\hline & & & IND & ING & MAT & MM & PAI & PPKN & KKPI \\
\hline 1 & 2100 & Achmad Amirrochbuna & 76.167 & 70.333 & 68.833 & 73.000 & 77.667 & 73.167 & 65.333 \\
\hline 2 & 2101 & Achmad Azizi Fadhil & $71.167^{\prime}$ & 54.667 & 62.667 & 62.833 & 73.500 & 70.500 & 60.167 \\
\hline 3 & 2102 & Achmad Iksan Maulana & $70.667^{\prime \prime}$ & 57.333 & 63.667 & 68.167 & 70.000 & '64.833' & 64.333 \\
\hline 4 & 2103 & Achmad Taqiyudin & $65.833^{\prime}$ & 51.333 & 60.833 & 68.333 & 75.833 & 69.500 & 58.333 \\
\hline 6 & 2105 & Afid Lipta Saputra & $74.000^{\prime}$ & 67.167 & 65.667 & 69.500 & 75.667 & 69.833 & 69.667 \\
\hline 7 & 2106 & Agus Tri Fatnanto & $73.833^{\prime}$ & 61.333 & 68.833 & 75.333 & 76.667 & '72.833' & 63.500 \\
\hline 8 & 2107 & Ahmad Ardi Yusuf & $67.500^{\prime}$ & 62.667 & 64.500 & 75.833 & 72.000 & '67.667" & 67.333 \\
\hline 9 & 2108 & Ahmad Echsanudin & $70.333^{\prime \prime}$ & 72.667 & 72.000 & 68.500 & 75.333 & '73.833" & 74.667 \\
\hline 10 & 2109 & Ahmad Farhan 'Azmi & $71.500^{\prime}$ & 68.333 & 64.000 & 61.500 & 71.667 & '70.667" & 67.500 \\
\hline 12 & 2111 & Ahmad Nur Fauzi "M" & $63.000^{\circ}$ & 59.167 & 59.000 & 68.167 & 66.833 & 64.500 & 63.333 \\
\hline 13 & 2112 & Ahmad Nur Fauzi "T" & $71.000^{\prime}$ & 69.500 & 62.667 & 74.500 & 73.167 & "71.833" & "71.667 \\
\hline 14 & 2113 & Ahmad Taufiqul Majid & $72.333^{\prime}$ & 62.333 & 63.500 & 73.667 & 77.333 & $72.000 "$ & 64.167 \\
\hline 15 & 2114 & Alfian Fauzi & $76.500^{\circ}$ & 71.667 & 69.667 & 66.333 & 77.333 & '76.833" & 71.167 \\
\hline 16 & 2115 & Alfin Nuryaddin & $72.000^{\prime}$ & 64.000 & 68.333 & 69.333 & 62.333 & 65.833 & 65.000 \\
\hline 17 & 2116 & Alif Khoirul Umam & $68.500^{\prime}$ & 68.333 & 71.333 & 64.667 & 68.000 & 65.500 & 64.833 \\
\hline 18 & 2117 & Anja Anwafi & $70.000^{\prime}$ & 68.667 & 73.667 & 66.000 & 72.833 & '74.333" & 68.000 \\
\hline 19 & 2118 & Ardika Gymnastiyar & $67.333^{\prime \prime}$ & 68.333 & 68.000 & 64.33 & 69.833 & 72.000 & 63.000 \\
\hline 20 & 2119 & As'ad Tahta Alfina & $70.000^{\prime}$ & 60.833 & 68.333 & 64.667 & 65.667 & 68.667 & 55.333 \\
\hline 21 & 2120 & Asif Sufyan & $69.500^{\prime}$ & 59.000 & 60.000 & 64.167 & 71.333 & '62.667" & 63.667 \\
\hline 22 & 2121 & Ayub & $72.000^{\prime}$ & 68.833 & 71.167 & 66.667 & 69.333 & 67.000 & 69.333 \\
\hline 23 & 2122 & Bachtiar Wisnu Dwi Putra & $70.333^{\prime}$ & 68.000 & 77.000 & 72.667 & 71.000 & "73.667" & "71.167 \\
\hline
\end{tabular}

Tabel 5. Nilai pusat cluster (centroid) awal untuk Bahasa Indonesia, Bahasa Inggris, dan Matematika

\begin{tabular}{|c|c|c|c|}
\hline No & NIS & Nama & IND \\
\hline 17 & 2116 & Alif Khoirul Umam & 68.500 \\
\hline 55 & 2154 & Moh. Naufal Irsyad & 63.167 \\
\hline 134 & 2233 & Midadatun Mila & 68.333 \\
\hline No & NIS & Nama & ING \\
\hline 33 & 2132 & Fauzal Maula L Rosjid & 67.333 \\
\hline 81 & 2180 & Muhammad Miftachudin & 65.000 \\
\hline 113 & 2212 & Amalia Isnaini Purinda Laksana & 68.167 \\
\hline No & NIS & Nama & MAT \\
\hline 57 & 2156 & Mufid Chariri Afnan & 63.000 \\
\hline 107 & 2206 & Wahyu Widhi Setyawan & 70.667 \\
\hline 151 & 2250 & Zida Rizqiyatunnisa & 71.333 \\
\hline
\end{tabular}


Tabel 6. Nilai pusat cluster (centroid) awal untuk MM, PAI, PPKn dan KKPI

\begin{tabular}{|c|c|c|c|}
\hline No & NIS & Nama & MM \\
\hline 35 & 2134 & Fuad Khoirul Anam & 70.667 \\
\hline 93 & 2192 & Mukhammad Muwaffaq Irby Umar & 70.500 \\
\hline 143 & 2242 & Siti Masfiah Lutfiana & 72.000 \\
\hline No & NIS & Nama & PAI \\
\hline 49 & 2148 & Khusni Aufa & 68.000 \\
\hline 87 & 2186 & Muhammad Saefudin & 66.333 \\
\hline 128 & 2227 & Ike Loveni Nur Safitri & 70.333 \\
\hline No & NIS & Nama & PPKn \\
\hline 12 & 2111 & Ahmad Nur Fauzi "M" & 63.000 \\
\hline 57 & 2156 & Mufid Chariri Afnan & 63.000 \\
\hline 136 & 2235 & Nailul Khasanatul Munawaroh & 63.667 \\
\hline No & NIS & Nama & KKPI \\
\hline 17 & 2116 & Alif Khoirul Umam & 68.500 \\
\hline 60 & 2159 & Muhamad Iqbal Fahmi & 64.500 \\
\hline 145 & 2244 & Syakila Fatkhia Rizki & 67.000 \\
\hline
\end{tabular}

Berdasarkan data tabel 4 ditentukan data nilai siswa yang masuk dalam kelompok belajar, dengan nilai di bawah 70,10. Nilai tersebut ditampilkan di tabel 7 sebagai berikut.

Tabel 7. Nilai Bahasa Indonesia $<70,10$

\begin{tabular}{|rrlr|}
\hline No & NIS & NAMA SISWA & NILAI \\
\hline 1 & 2103 & Achmad Taqiyudin & 65.833 \\
2 & 2107 & Ahmad Ardi Yusuf & 67.500 \\
3 & 2111 & Ahmad Nur Fauzi "M" & 63.000 \\
4 & 2116 & Alif Khoirul Umam & 68.500 \\
5 & 2118 & Ardika Gymnastiyar & 67.333 \\
6 & 2120 & Asif Sufyan & 69.500 \\
7 & 2123 & Bayu Ridho Alwi & 69.833 \\
8 & 2124 & Chabib Kurniawan & 63.833 \\
9 & 2125 & Choirul Wafa Fatchul Kaefan & 63.000 \\
10 & 2126 & Dandi Mulya Dian Saputra & 66.000 \\
11 & 2127 & Deni Widianto & 67.833 \\
12 & 2129 & Fajar Pambudi & 69.000 \\
13 & 2130 & Farih Abdul Rouf & 68.667 \\
14 & 2131 & Fatkhan Ainun Najib & 66.833 \\
15 & 2132 & Fauzal Maula L Rosjid & 67.333 \\
16 & 2133 & Fauzi Lathiful Ichsan & 66.000 \\
17 & 2135 & Gayuh Rizqi Adiguna & 64.333 \\
18 & 2137 & Akhmad Muhammad Wahyu Bin & 67.333 \\
19 & 2138 & Farhan Yasin Abdilah & 67.333 \\
20 & 2139 & Hafidz Qaulan Tsaqyla & 53.000 \\
21 & 2140 & Hafiz Muhamad Choirurrozi & 59.500 \\
22 & 2141 & Hamam Rifki & 68.000 \\
23 & 2142 & Handy Alfian Saputra & 69.333 \\
\hline
\end{tabular}

Melalui tabel 7 di atas, terdapat 111 siswa untuk mata pelajaran Bahasa Indonesia, 131 siswa untuk mata pelajaran Bahasa Inggris, 121 siswa untuk mata pelajaran matematika, 120 siswa untuk mata pelajaran multimedia, 88 siswa untuk mata pelajaran PAI, 100 siswa untuk mata pelajaran PPKN, dan 122 siswa untuk mata pelajaran KKPI. Semua data siswa yang dapat masuk ke dalam kelompok belajar terlampir dalam tabel 8 .

Tabel 8. Jumlah Siswa untuk kelompok belajar

\begin{tabular}{|lc|}
\hline Mata Pelajaran & Jml Siswa \\
\hline Bahasa Indonesia & 111 \\
Bahasa Inggris & 131 \\
Matematika & 121 \\
Multimedia & 120 \\
PAl & 88 \\
PPKn & 100 \\
KKPI & 122 \\
\hline
\end{tabular}

\subsection{Menentukan Cluster dalam kelompok MaPel}

Proses perhitungan dengan menggunakan algoritma KMeans setelah menentukan pusat centroid awal selanjutnya adalah menentukan kelompok mata pelajaran. Penentuan centroid awal ditentukan secara acak dari data nilai rata-rata siswa, kemudian untuk jumlah cluster ditentukan sebanyak 3 cluster.

Tabel 9. Kelompok Bahasa Indonesia dengan centroid awal (23 siswa)

\begin{tabular}{|c|c|c|c|c|c|c|c|}
\hline \multirow{2}{*}{ NO NIS } & \multirow{2}{*}{ NAMA SISWA } & \multicolumn{3}{|c|}{ Centroid } & \multicolumn{3}{|c|}{ Cluster } \\
\hline & & 68.500 & 63.167 & 68.333 & C1 & C2 & C3 \\
\hline 12103 & Achmad Taqiyudin & 2.667 & 2.667 & 2.500 & - & - & 1 \\
\hline 22107 & Ahmad Ardi Yusuf & 1.000 & 4.333 & 0.833 & - & - & 1 \\
\hline 32111 & Ahmad Nur Fauzi "M" & 5.500 & 0.167 & 5.333 & - & 1 & - \\
\hline 42116 & Alif Khoirul Umam & 0.000 & 5.333 & 0.167 & 1 & - & - \\
\hline 52118 & Ardika Gymnastiyar & 1.167 & 4.167 & 1.000 & - & - & 1 \\
\hline 62120 & Asif Sufyan & 1.000 & 6.333 & 1.167 & 1 & - & - \\
\hline 72123 & Bayu Ridho Alwi & 1.333 & 6.667 & 1.500 & 1 & - & - \\
\hline 82124 & Chabib Kurniawan & 4.667 & 0.667 & 4.500 & - & 1 & - \\
\hline 92125 & Choirul Wafa Fatchul Kaefan & 5.500 & 0.167 & 5.333 & - & 1 & - \\
\hline 102126 & Dandi Mulya Dian Saputra & 2.500 & 2.833 & 2.333 & - & - & 1 \\
\hline 112127 & Deni Widianto & 0.667 & 4.667 & 0.500 & - & - & 1 \\
\hline 122129 & Fajar Pambudi & 0.500 & 5.833 & 0.667 & 1 & - & - \\
\hline 132130 & Farih Abdul Rouf & 0.167 & 5.500 & 0.333 & 1 & - & - \\
\hline 142131 & Fatkhan Ainun Najib & 1.667 & 3.667 & 1.500 & - & - & 1 \\
\hline 152132 & Fauzal Maula L Rosjid & 1.167 & 4.167 & 1.000 & - & - & 1 \\
\hline 162133 & Fauzi Lathiful Ichsan & 2.500 & 2.833 & 2.333 & - & - & 1 \\
\hline 172135 & Gayuh Rizqi Adiguna & 4.167 & 1.167 & 4.000 & - & 1 & - \\
\hline 182137 & Akhmad Muhammad Wahyu B & 1.167 & 4.167 & 1.000 & - & - & 1 \\
\hline 192138 & Farhan Yasin Abdilah & 1.167 & 4.167 & 1.000 & - & - & 1 \\
\hline 202139 & Hafidz Qaulan Tsaqyla & 15.500 & 10.167 & 15.333 & - & 1 & - \\
\hline 212140 & Hafiz Muhamad Choirurrozi & 9.000 & 3.667 & 8.833 & - & 1 & - \\
\hline 222141 & Hamam Rifki & 0.500 & 4.833 & 0.333 & - & - & 1 \\
\hline 232142 & Handy Alfian Saputra & 0.833 & 6.167 & 1.000 & 1 & - & - \\
\hline
\end{tabular}

Berdasarkan tabel 9 di atas, penentuan centroid $(\mathrm{C} 1, \mathrm{C} 2$, C3) berdasarkan rumus dari persamaan berikut.

$$
d_{(x, y)}=\|x-y\|^{2}=\sqrt{\sum_{i=1}^{n}(x i-y i)^{2}}
$$

\subsection{Menentukan Nilai Mean tiap Cluster dalam kelompok Mata Pelajaran}

Proses perhitungan selanjutnya adalah menghitung nilai mean atau nilai rata-rata untuk semua cluster dalam kelompok mata pelajaran. Berdasarkan perhitungan sebelumnya, diketahui bahwa untuk kelompok Bahasa Indonesia terdapat 15 siswa untuk clusterl, 61 siswa untuk cluster 2,35 siswa untuk cluster3. Hasil perhitungan nilai rata-rata (mean) ditunjukkan dalam tabel 10 di bawah ini.

Tabel 10. Nilai mean yang akan dijadikan nilai centroid selanjutnya

\begin{tabular}{|c|c|c|c|}
\hline & C1 & $\mathrm{C2}$ & C3 \\
\hline Bhs.Indonesia & 68.736 & 61.186 & 65.966 \\
\hline Bhs.Inggris & 52.695 & 0.000 & 0.000 \\
\hline Matematika & 56.357 & 58.724 & 0.000 \\
\hline Multimedia & 0.000 & 58.396 & 0.000 \\
\hline PAI & 66.629 & 61.519 & 69.198 \\
\hline PPKn & 0.000 & 0.000 & 65.632 \\
\hline KKPI & 68.722 & 60.423 & 65.302 \\
\hline
\end{tabular}

Tabel 10 di atas merupakan tabel hasil perhitungan mean dari semua kelompok mata pelajaran. Berdasarkan hasil 
tabel 10 tersebut, maka diperoleh data centroid (pusat cluster) yaitu nilai mean dari setiap cluster. Proses ini akan terus dilakukan sampai data tidak berubah dalam setiap clusternya. Proses perhitungan selanjutnya adalah dengan menerapkan rumus di atas, sehingga perhitungannnya seperti berikut:

Data nilai untuk NIS $=2103$, nama Achmad Taqiyudin

Centroid $1=\operatorname{SQRT}\left((65.833-68.500)^{\wedge}\right.$ ^ 2$)=2.667$

Centroid $2=\operatorname{SQRT}\left((65.833-63.167)^{\wedge} 2\right)=2.667$

Centroid $3=\operatorname{SQRT}\left((65.833-68.333)^{\wedge} 2\right)=2.500$

Sedangkan untuk menentukan cluster 1, 2 atau 3 adalah berdasarkan logika berikut ini:

Cluster 1 = IF (Centroid $1<$ Centroid 2, IF (Centroid $1<$ Centroid 3,1,"- "),"- ")

Cluster 2 = IF (Centroid $2<$ Centroid 3, IF (Centroid $2<$ Centroid 1,1,"- "),"- ")

Cluster 3 = IF (Centroid $3<$ Centroid 1, IF (Centroid $3<$ Centroid 2,1,"- "),"- ")

Berdasarkan perintah logika di atas, maka hasil cluster untuk NIS = 2103 adalah cluster 3 (C3).

\section{Kesimpulan}

Berdasarkan pembahasan di atas, dengan menerapkan KMeans untuk membentuk kelompok belajar sesuai dengan mata pelajaran UN (Ujian Nasional) yaitu Bahasa Indonesia, Bahasa Inggris, Matematika, MM, PAI, PPKN, dan KKPI terlampir di tabel 11 yang menampilkan jumlah cluster yang dihasilkan dalam setiap kelompok mata pelajaran.

Tabel 11. Jumlah Cluster yang dihasilkan

\begin{tabular}{|c|c|c|c|c|c|c|c|c|c|c|c|c|c|c|c|}
\hline \multirow{2}{*}{ 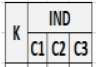 } & \multirow[b]{2}{*}{ k } & \multicolumn{2}{|l|}{\begin{tabular}{|c|} 
ING \\
\end{tabular}} & & MAT & & MM & \multirow{2}{*}{ K } & \multirow{2}{*}{ 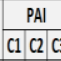 } & & \multicolumn{3}{|c|}{ PPKN } & \multirow{2}{*}{$k$} & \multirow{2}{*}{ 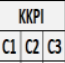 } \\
\hline & & \begin{tabular}{|l|l|}
$\mathrm{C} 1$ & $\mathrm{C}$ \\
\end{tabular} & & & 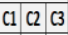 & & $\begin{array}{lll}C_{1} & \mathrm{Cl} \\
\end{array}$ & & & & & & $C 3$ & & \\
\hline \begin{tabular}{lllll|}
1 & 15 & 61 & 35 \\
\end{tabular} & 1 & 12103 & 16 & 1 & \begin{tabular}{l|l|l}
86 & 35 & 0 \\
\end{tabular} & 1 & 0120 & 1 & 1957 & & & & 82 & 1 & $\begin{array}{lll}26 & 79 & 17 \\
\end{array}$ \\
\hline 195042 & 2 & 12110 & 0 & & \begin{tabular}{l|l|l|}
24 & 97 & 0 \\
\end{tabular} & 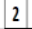 & $\begin{array}{ll}0 & 120 \\
\end{array}$ & & 3044 & & & & 100 & 2 & 25623 \\
\hline \begin{tabular}{l|l|l|l|l|l|} 
& 19 & 50 & 42 \\
\end{tabular} & 3 & $121 \quad 10$ & 0 & 3 & \begin{tabular}{l|l|l|l|}
24 & 97 & 0 \\
\end{tabular} & 3 & \begin{tabular}{|l|l|}
0 & 120 \\
\end{tabular} & 3 & \begin{tabular}{|l|l|}
30 & 44 \\
\end{tabular} & 3 & 0 & & 100 & 3 & \begin{tabular}{l|l|l}
25 & 62 & 35 \\
\end{tabular} \\
\hline \begin{tabular}{lllll|l} 
& 24 & 43 & 44 \\
\end{tabular} & 4 & 1310 & 0 & 4 & $7114 \quad 0$ & 4 & $\begin{array}{lll}0 & 120 \\
\end{array}$ & 4 & \begin{tabular}{|l|l|}
31 & 36 \\
\end{tabular} & & 0 & & 100 & 4 & $\begin{array}{llll}30 & 50 & 42\end{array}$ \\
\hline \begin{tabular}{|l|l|l|l|l|l|l|} 
& 24 & 43 & 44
\end{tabular} & 5 & 1310 & 0 & 3 & 71140 & 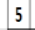 & \begin{tabular}{ll|}
0 & 120 \\
\end{tabular} & 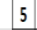 & 31 36 & & 10 & & 100 & 5 & $30 \quad 50 \quad 42$ \\
\hline \begin{tabular}{lllll|}
6 & 24 & 43 & 44
\end{tabular} & 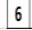 & 1310 & 0 & & 711140 & & 0120 & 6 & 3136 & & & & 100 & 6 & $\begin{array}{llll}30 & 50 & 42\end{array}$ \\
\hline
\end{tabular}

Merujuk tabel 11 di atas, diketahui $\mathrm{K}$ adalah proses urutan K-means (dari 1 s.d 6), dan proses berhenti pada saat K ke 6, karena jumlah cluster tidak berubah. Jumlah siswa untuk kelompok IND cluster 1 terdapat 24 siswa, cluster 2 terdapat 43 siswa, dan cluster 3 terdapat 44 siswa, dan untuk kelompok ING cluster 1 terdapat 131 siswa, cluster 2 dan cluster 3 tidak ada siswa, kelompok MAT cluster 1 terdapat 7 siswa, cluster 2 terdapat 114 siswa, dan cluster 3 tidak ada siswa, kelompok MM cluster 1 dan cluster 3 tidak ada siswa, tetapi cluster 2 terdapat 120 siswa, kelompok PAI cluster 1 terdapat 31 siswa, cluster 2 terdapat 36 siswa, dan cluster 3 terdapat 21 siswa, kelompok PPKN cluster 1 dan cluster 2 tidak ada siswa, tetapi cluster 3 terdapat 100 siswa, selanjutnya kelompok KKPI cluster 1 terdapat 30 siswa, cluster 2 terdapat 50 siswa, dan cluster 3 terdapat 42 siswa.

Berdasarkan hasil yang telah didapat melalui tabel 11, maka dapat diketahui siswa dengan NIS berapa saja yang masuk di dalam cluster per kelompok mata pelajaran, yang terlampir di tabel 12 berikut.
Tabel 12. Data Siswa dalam Kelompok Belajar (Ind, Ing, Mat, MM)

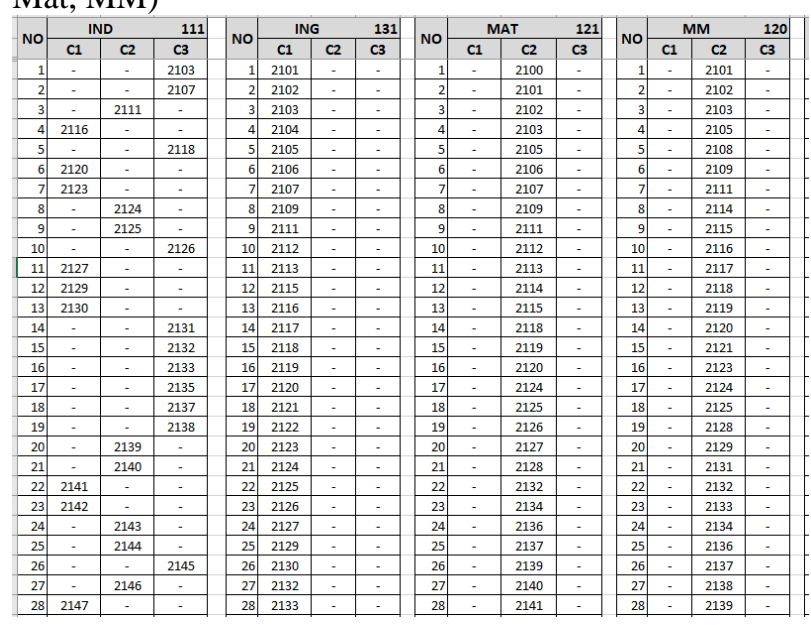

Tabel 13. Data Siswa dalam Kelompok Belajar (PAI, PPKN, KKPI)

\begin{tabular}{|c|c|c|c|c|c|c|c|c|c|c|c|}
\hline \multirow{2}{*}{ NO } & \multicolumn{2}{|c|}{ PAI } & \multirow{2}{*}{\begin{tabular}{|l|}
88 \\
$C 3$
\end{tabular}} & \multirow{2}{*}{ NO } & \multicolumn{2}{|c|}{ PPKN } & \multirow{2}{*}{$\frac{100}{C 3}$} & \multirow{2}{*}{ NO } & \multicolumn{2}{|c|}{ KKPI } & \multirow{2}{*}{$\begin{array}{l}122 \\
\mathrm{C} 3\end{array}$} \\
\hline & C1 & C2 & & & C1 & C2 & & & C1 & C2 & \\
\hline 1 & 2111 & - & - & 1 & - & - & 2102 & 1 & - & - & 2100 \\
\hline 2 & - & 2115 & - & 2 & - & - & 2103 & 2 & - & 2101 & - \\
\hline 3 & 2116 & - & - & 3 & - & - & 2105 & 3 & - & - & 2102 \\
\hline 4 & - & - & 2118 & 4 & - & - & 2107 & 4 & - & 2103 & - \\
\hline 5 & 2119 & - & - & 5 & - & - & 2111 & 5 & - & - & 2104 \\
\hline 6 & - & - & 2121 & 6 & - & - & 2115 & 6 & 2105 & - & - \\
\hline 7 & 2123 & - & - & 7 & - & - & 2116 & 7 & - & 2106 & - \\
\hline 8 & - & 2124 & - & 8 & - & - & 2119 & 8 & - & - & 2107 \\
\hline \begin{tabular}{l|l}
9 \\
\end{tabular} & 2125 & - & - & 9 & - & - & 2120 & 9 & - & - & 2109 \\
\hline 10 & 2128 & - & - & 10 & - & - & 2121 & 10 & - & 2111 & - \\
\hline 11 & - & - & 2130 & 11 & - & - & 2128 & 11 & - & - & 2113 \\
\hline 12 & - & 2132 & - & 12 & - & - & 2130 & 12 & - & - & 2115 \\
\hline \begin{tabular}{l|l|}
13 \\
\end{tabular} & - & 2133 & - & 13 & - & - & 2131 & 13 & - & - & 2116 \\
\hline 14 & - & - & 2134 & 14 & - & - & 2133 & 14 & 2117 & - & - \\
\hline 15 & - & 2137 & - & 15 & - & - & 2135 & 15 & - & 2118 & - \\
\hline 16 & 2138 & - & - & 16 & - & - & 2136 & 16 & - & 2119 & - \\
\hline 17 & - & 2139 & - & 17 & - & - & 2137 & 17 & - & - & 2120 \\
\hline \begin{tabular}{l|l}
18 \\
\end{tabular} & - & 2140 & - & 18 & - & - & 2138 & 18 & 2121 & - & - \\
\hline 19 & 2141 & - & - & 19 & - & - & 2139 & 19 & - & 2123 & - \\
\hline 20 & 2142 & - & - & 20 & - & - & 2140 & 20 & - & 2124 & - \\
\hline 21 & - & 2145 & - & 21 & - & - & 2141 & 21 & - & - & 2125 \\
\hline 22 & - & 2146 & - & 22 & - & - & 2142 & 22 & 2126 & - & - \\
\hline \begin{tabular}{|l|}
23 \\
\end{tabular} & - & - & 2147 & 23 & - & - & 2143 & 23 & - & - & 2128 \\
\hline 24 & 2148 & - & - & 24 & - & - & 2144 & 24 & - & 2130 & - \\
\hline 25 & - & 2150 & - & 25 & - & - & 2145 & 25 & 2131 & - & - \\
\hline \begin{tabular}{|l|}
26 \\
\end{tabular} & - & - & 2151 & 26 & - & - & 2146 & 26 & - & - & 2133 \\
\hline 27 & 2152 & - & - & 27 & - & - & 2147 & 27 & 2135 & - & - \\
\hline 28 & - & 2153 & - & 28 & - & - & 2148 & 28 & - & - & 2137 \\
\hline
\end{tabular}

\section{Daftar Pustaka}

UU REPUBLIK INDONESIA no.20 tahun 2003 tentang Pendidikan

PERMENDIKBUD NO.14 TH 2017 tentang pendidikan

FENTY EKA M, 2015. Implementasi Algoritma K-Means Untuk Kelompok Pengayaan Materi Mata Pelajaran Ujian Nasional, Jurnal Teknik Informatika, Vol 8 No.1:73.

ANINDYAN KHRISNA, Implementasi Algoritma $K$ Means Untuk Pengelompokkan Penyakit Pasien Pada PusKesMas Kajen Pekalongan, Jurnal Transformatika, Vol 14 No.1:30, 2016.

ASRONI, RONALD ADRIAN. Penerapan Metode $K$ Means Untuk Clustering Mahasiswa Berdasarkan Nilai Akademik Dengan Weka Interface Studi Kasus Pada Jurusan Teknik Informatika UMM Magelang, Jurnal Ilmiah Semesta Teknika, Vol.18 No. 1,76 - 82, Mei 2015 
ABDUL KADIR, 2003. Konsep dan Tuntunan Praktis Basis Data. Yogyakarta.

J.O.ONG, Implementasi Algoritma K-Means Clustering Untuk Menentukan Strategi Marketing President University. Jurnal Ilmiah Teknik Industri, vol. 12, no. 1, pp. 10 - 20, 2013

OTHMAN IBRAHIM, MEHRBAKHSH NILASHI, KARAMOLLAH BAGHERIFARD, NOUROOZ HASHEMI, NASIM JANAHMADI, MOUSA BARISAMI, Application of AHP and K-Means Clustering for Ranking and Classifying Customer Trust in M-commerce. Australian Journal of Basic and Applied Sciences 5(12): 1441-1457, 2011

SANTOSA, B. 2007. Data Mining: Teknik Pemanfaatan Data untuk Keperluan Bisnis. Yogyakarta: Graha Ilmu.

HAN JIAEWI, KAMBER MICHELINE 2006. Data Mining : Concepts and techniques, second edition. Elsevier. p.460

EDIYANTO, MUHLASAH NOVITASARI M. NEVA SATYADEWI. Pengklasifikasian Karakteristik Dengan Metode K-Means Cluster Analysis, Buletin Ilmiah Mat. Stat. dan Terapannya (Bimaster), Vol 2 , No. 2,133 - 136, th 2013.

SUPRIHATIN. Klastering K-Means untuk Penentuan Nilai Ujian. JUSI. Vol.1 No.1 : 53, 2011 